\title{
Leflunomide an Immunosuppressive Drug for Antiviral Purpose in Treatment for BK Virus-Associated Nephropathy After Kidney Transplantation
}

\author{
Christophe Bazin \\ Hôpital Européen Georges-Pompidou, Assistance Publique - Hôpitaux de Paris
}

France

\section{Introduction}

\subsection{BK Virus}

$\mathrm{BK}$ virus is a polyomavirus belonging to the papovaviridae branch. In addition to $\mathrm{BK}$, the human polyomavirus family includes John Cunningham virus (JCV), Washington University virus (WUV), Karolinska Institute virus (KIV) and Merkel cell viruses (Boothpur et al. 2010). BK virus is a virus without a shell and it has a double-stranded circular nonenveloped DNA. It was first discovered and isolated in 1971 just like JC virus, responsible for Progressive Multifocal Leukoencephalopathy (PML). Contamination usually occurs during early childhood through the airway without clinical symptoms. BK virus seroprevalence in general population is around $60 \%$. The main latency areas are the kidney and the urothelium. Asymptomatic BK virus infection is often acquired in childhood and the virus persists in a dormant state in urothelium and kidneys of healthy and immunocompetent individuals, where it can be reactivated under immunosuppression (Nickeleit et al. 2000a; Brocker et al. 2011).

\subsection{Prevalence and incidence}

Urinary viral prevalence for BK virus is between $0.3 \%$ and $6 \%$ in general population, and increases in functions of immunosuppression degree; between $10 \%$ and $45 \%$ in patients after renal transplant, $30 \%$ in patients after bone marrow graft and $25 \%$ in patients with Human immunodeficiency virus. In patients with renal graft, the annual incidence of the nephropathy is between 3\% and 5\% (Randhawa et al. 2000; Pavlakis et al. 2006).

\subsection{Risk factors}

BK virus-associated nephropathy seems to be promoted by the concurrent presence of several risk factors. The immunosuppressive regimen strength, with high level blood concentrations, is the first factor involved. Most patients affected by BK virus-associated nephropathy previously had an intensification of immunosuppressive regimen due to a rejection event or a treatment including tacrolimus and/or mycophenolate mofetil 
combined with monoclonal or polyclonal antibodies (De Luca et al. 2000; Nickeleit et al. 2000b; Randhawa et al. 2000; Hirsch et al. 2001). Conversely, no cases have been reported in patients treated with cyclosporine and corticosteroids (Binet et al. 1999; Mengel et al. 2003).

The other risk factors identified comprise donor characteristics, such as female gender, deceased donation, ischemia-reperfusion injury, high BK virus specific antibody titres, HLA mismatch and African-American ethnicity. The recipient characteristics in cause are older age, male gender, white race, diabetes, obesity, retransplantation, lack of HLA C-7, low or absent BK virus specific T-cell activity. Lastly, in addition to high immunosuppressive drug levels and tacrolimus based combinations, other post-transplant factors can be mentioned as acute rejection and antirejection treatment, cumulative steroid exposure and lymphocyte depleting antibodies (Gupta \& Gupta, 2011).

Although immunosuppression increases the probability of latent BK virus reactivation, clinical manifestation of disease is rare. When symptoms occur, on the clinical point of view, a progressive decline of the renal functions can be observed up to $45 \%$ of patients, usually 9 to 12 months after the renal transplant (Nickeleit et al. 2000a; Randhawa et al. 2000). The most serious form of the infection turns out to be the interstitial nephritis; although the BK virus was discovered in the 70's, this serious complication has first been seen in 1995. This fact can probably be explained by the commercialization of two drugs in 1995 and 1996, tacrolimus and mycophenolate mofetil.

Interestingly, BK virus-associated nephropathy happens hardly only in patients with renal graft. Some explanations could be found, such as the role of vesico-urethral reflux, quite usual in renal transplantation, with the systemic pathway of collecting tubes in peritubular capillary and the tubular localization of the infection. Some authors evoked easiness in the viral antigens presentation in a context of allograft, cold ischemia, tubular necrosis and graft rejection. For that matter BK virus-associated nephropathy is generally related to rejection, both events being linked in time; most cases of nephropathy are falsely tagged and treated just like a rejection. This confusion suggests that rejection is a risk factor on its own. Viral antigens could probably lead to rejection and conversely a rejection event could reactivate viral replication. In mice, Atencio et al proved an inductive effect of tubular damage upon BK virus linked interstitial nephritis (Atencio et al. 1993).

\subsection{Clinical aspects}

BK virus infection may lead to encephalitis, retinitis, pneumonitis, damage of the kidneys, bleeding of the bladder, and blockage of urine passageways. Minor infections are most of the time asymptomatic and can lead to urethral stenosis. This infection occurs 1 to 45 months (average 12.5 months) after the graft. It is linked to the conjunction of multiple factors, including an intense immunosuppressive regimen, viral reactivation, existence of an immune-allogenic conditions, and a suffering tubular due to ischemia or rejection (Nickeleit et al. 2003).

\subsection{Genotypes}

BK virus comes in the form of 4 different genotypes, type I being the most common seen. The coding regions for non structural proteins $\mathrm{T}$ and $\mathrm{t}$ antigens (pathogenic viral power), viral capsid proteins (cellular tropism) and a regulatory non coding zone have a vital 
importance. Some authors have brought to light emerging mutations which could explain the renal physiopathologic effects of these viruses (Chen et al. 2001). Virus selection in patients with renal graft results in rearrangements in the $\mathrm{T}$ antigen region, mutations in the non coding regulatory zone, and above all variations in VP1 protein (Smith et al. 1998; Baksh et al. 2001; Randhawa et al. 2002). Heterogeneity and genetic instability in a same patient seem to favor renal damage and the risk of escaping immunologic surveillance (Chen et al. 2001; Randhawa et al. 2002).

\subsection{Histology}

BK virus is usually associated with changes in the kidney and sometimes haemorrhagic cystitis and urethral stenosis. The virus affects tubular epithelial cells that show characteristic intranuclear inclusion bodies. Diagnosis relies upon urinary cytology, detection of viral DNA in fluids and renal biopsy. The nephropathy diagnosis can only be made histologically in a graft biopsy. Intranuclear viral inclusions are exclusively seen in epithelial cells and tubular cells reveal focal necrosis. Four different variants of intranuclear inclusion bodies can be seen throughout the entire nephron. Type 1 is the most frequently observed; it is an amorphous basophilic ground-glass variant. Type 2 is an eosinophilic granular type, halo surrounded. Type 3 is a finely granular form lacking a halo. And finally type 4 is a vesicular variant presenting markedly enlarged nuclei and irregular chromatin. Infected cells which are rounded-up and extruded from the epithelial cell layer into tubular lumens are frequently observed. Viral replication often causes tubular epithelial cell necrosis with denudation of basement membranes. Although cytopathic signs can be seen along the entire nephron, they are mostly abundant in distal tubular parts and collecting ducts (Nickeleit et al. 2000a).

\subsection{Interstitial inflammation}

Interstitial inflammation in BK virus-associated nephropathy still remains controversial and needs to be fully explained. The major outcome is to distinguish between virally induced interstitial nephritis and cellular rejection. As lowering immunosuppression is the first option which can be chosen in the treatment, this choice requires two conditions, first the absence of rejection and second the BK virus should not trigger rejection. BK virus is frequently accompanied by an heterogeneous inflammatory reaction (Drachenberg et al. 1999). This inflammation can be minimal or absent in up to $17 \%$ of biopsies (Nickeleit et al. 2000a). When inflammation is encountered, the inflammatory cell infiltrate is composed of lymphocytes, macrophages and occasional plasma cells. Polymorphonuclear leukocytes can be seen in response to markedly damaged tubules with urinary leakage (Drachenberg et al. 1999). About $50 \%$ of biopsies performed during persistent BK virus-associated nephropathy show evidence of cellular rejection as conventionally defined with abundant tubulitis and transplant endarteritis in about $25 \%$. Typically, mononuclear cell infiltrates and tubulitis are pronounced in areas without viral inclusions making virally induced interstitial nephritis highly unlikely (Nickeleit et al. 2000a).

The upregulation of MCH-class II (HLA-DR) and ICAM-1 on tubular epithelial cells is a typical finding in graft biopsies with cellular rejection and can serve as an adjunct diagnostic tool (Seron et al. 1989; Nickeleit et al. 1998). HLA-DR expression can stimulate an allogenic 
lymphocytic reaction and also enhance $\mathrm{T}$ cell mediated lysis (Rosenberg et al. 1992). Consequently, BK virus could probably trigger rejection episodes by inducing HLA-DR upregulation as previously proposed for CMV (von Willebrand et al. 1986). However, no association could be found between BK virus infection and tubular HLA-DR expression based on immunofluorescence double labeling staining techniques. It is only in biopsies showing characteristic morphological evidence of rejection with marked tubulitis that typical upregulation of HLA-DR and ICAM-1 could be observed (Nickeleit et al. 2000a). Therefore, BK virus does not stimulate HLA-DR expression. Consequently no significant difference can be found between the prevalence of rejection in tissue samples taken during persistent BK virus-associated nephropathy and time matched controls without BK virus nephropathy. Thus, BK virus does not seem to provoke a constant and pronounced interstitial inflammatory reaction and should probably not be considered as associated with an increased prevalence of rejection episodes (Nickeleit et al. 2000a).

\subsection{PCR}

BK-virus DNA in the plasma and the urine, which can be detected by PCR (Polymerase Chain Reaction), is closely associated with nephropathy. Quantitative PCR can be used to follow the disease evolution and the treatment efficiency (Randhawa et al. 2004).

As for BK virus infection, this technique has proven a $100 \%$ sensivity, a $88 \%$ specificity and above all a negative predictive test of $100 \%$. Hirsch et al. have even shown a correlation between viral load and nephropathy and proposed a cut-off above which the risk of nephropathy is significant: all patients with more than 7700 copies/mL in plasma had typical BK virus-associated nephropathy lesions on the biopsy (Hirsch et al. 2002).

The nephropathy evolution is very poor with a cytopathogenic effect persistent in up to $70 \%$ of patients, a graft loss in $45 \%$ of cases; and major sequel fibrosis in $75 \%$ of cases, even if viremia can be controlled (Nickeleit et al. 2000a; Randhawa et al. 2000; Mylonakis et al. 2001; Mengel et al. 2003).

\section{Classical treatments for BKV nephropathy}

Therapeutic alternatives are quite few in number. Despite the absence of randomized clinical trials, the current approach generally includes reduction of immunosuppression (Brennan et al. 2005; Hardinger et al. 2010). The rational is to allow host immune function to combat the virus, with the risk to increase acute and subclinical rejection. Lowering immunosuppression with smaller dosage and/or less drugs is partially efficient and seems to be the first thing to do. Except from lowering immunosuppression, to date no treatment seem to be efficient enough to be recommended to all patients, and new research have to be performed because of the poor evidence in small series of patients (Johnston et al. 2010).

\subsection{Lowering immunosuppression}

Reduction of immunosuppression is to date the only consensus regarding the treatment of BK virus-associated nephropathy. Lowering tacrolimus dosage of $41 \%$ and mycophenolate mofetil dosage of $44 \%$ allowed to eradicate 24 patients' viremia in 6 months (Saad et al. 2008). 
In a previous study, mycophenolate mofetil was stopped the day leflunomide treatment was initiated; tacrolimus and everolimus were respectively reduced of $50 \%$ and $12.5 \%$. Therapeutic drug monitoring target for tacrolimus was lowered to $4-6 \mathrm{ng} / \mathrm{mL}$ on immunoenzymatic techniques on whole blood. Corticosteroids were kept with average dosage of 5 to $10 \mathrm{mg}$ per day (Bazin et al. 2009). Other authors recommend even lower targets with $3 \mathrm{ng} / \mathrm{mL}$ for tacrolimus and $100 \mathrm{ng} / \mathrm{mL}$ for cyclosporine (Gupta \& Gupta, 2011).

Besides, lowering immunosuppressive regimens together with a specific treatment for BK virus-associated nephropathy recently turns out to be effective to prolong graft survival, and moreover a safe treatment with acute rejection rates not increased significantly after lowering immunosuppression (Dheir et al. 2011).

Two different therapeutic strategies have been evaluated: the immunosuppression withdrawal (3-drug to 2-drug immunosuppression) within the first month versus reduction of immunosuppression. The regimen modifications and results are presented in table 1 and figure 1 . The Withdrawal cohort had significantly better graft survival at 1 year compared with the Reduction cohort (1-year graft survival $87.8 \%$ versus $56.2 \%, \mathrm{P}=0.03$ ) (Weiss et al. 2008).

\begin{tabular}{|l|c|c|c|}
\hline & $\begin{array}{c}\text { Withdrawal } \\
\text { cohort } \\
(n=17)\end{array}$ & $\begin{array}{c}\text { Reduction } \\
\text { cohort } \\
(n=18)\end{array}$ & $\mathrm{p}$ \\
\hline CNI, sirolimus, prednisone at diagnosis & 12 & 11 & 0.56 \\
CNI, MMF, prednisone at diagnosis & 5 & 7 & 0.56 \\
Median serum creatinine at diagnosis (mg/dl) & 2.5 & 2.2 & 0.30 \\
Agent withdrawal within 1 mo of diagnosis & 14 & - & - \\
$\quad$ CNI withdrawal & 3 & - & - \\
AP withdrawal & - & 8 & - \\
Dose reduction within 1 mo of diagnosis & - & 7 & - \\
$\quad$ CNI reduction, AP reduction $<50 \%$ & - & 3 & - \\
$\quad$ CNI reduction, AP reduction $\geq 50 \%$ & 2 & 5 & 0.40 \\
Tac to CsA switch, AP reduction $<50 \%$ & 8 & 8 & 0.88 \\
Ancillary therapy & 4 & 5 & 1.0 \\
$\quad$ Cidofovir & 1 & 1 & 1.0 \\
$\quad$ Intravenous Ig & & & \\
Leflunomide & & & \\
Acute rejection after diagnosis & & & \\
\hline
\end{tabular}

Table 1. Immunosuppression modifications comparing immunosuppression withdrawal versus immunosuppression reduction after diagnosis of BK virus-associated nephropathy. CNI, calcineurin inhibitor; MMF, mycophenolate; AP, antiproliferative; Tac, tacrolimus; CsA, cyclosporine A (Weiss et al. 2008).

\subsection{Cidofovir}

Cidofovir (Vistide ${ }^{\circledR}$ ) is an injectable antiviral drug. It belongs to nucleoside analogues. It is used in infections due to human Cytomegalovirus (CMV) in adults suffering of AIDS (Acquired immune deficiency syndrome) without renal insufficiency, and it should only be used when other treatments are considered as inappropriate. Cidofovir counters CMV replication thanks to a selective inhibition of viral DNA polymerase in herpesviridae viruses 


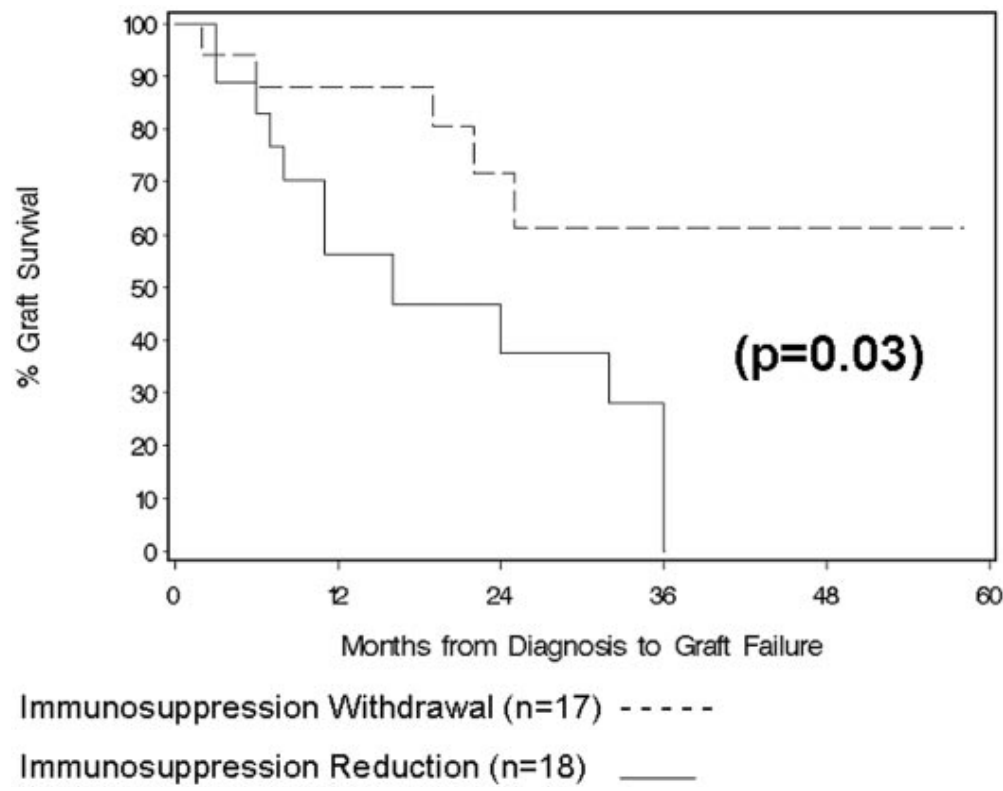

Fig. 1. Immunosuppression withdrawal preserves graft function compared with reduction (Weiss et al. 2008).

(Gilead 2010). Cidofovir has also demonstrated in vitro activity against murine and simian polyomavirus strains and appears to have activity against JC virus in vivo (De Luca et al. 2000). Pharmacokinetic studies have demonstrated that cidofovir is highly concentrated in urine and renal tissue which are the primary sites of BK virus infection (Kadambi et al. 2003). This fact highlights the possibility that low doses might be sufficient for treating an infectious process, such as BK virus-associated nephropathy, that appears to be largely localized to the kidney and genitourinary tract.

The treatment consists in a low-dose treatment, $0.25 \mathrm{mg} / \mathrm{kg} /$ day intravenous during 2 weeks, associated to a prior hydration of 1 litre of saline solution. Cidofovir seems to be efficient in BK virus as well, but it tends to concentrate itself inside the kidney and can be responsible of a nephrotoxicity mostly for tubular cells leading to renal insufficiency.

Few cases have been described in literature and no conclusion can be given on the real efficacy of cidofovir. Indeed, despite viremia control, viruria remains detectable and the treatment is not able to avoid the evolution towards fibrosis and renal insufficiency (Kadambi et al. 2003; Kuypers et al. 2005).

In some cases, cidofovir may also become deleterious (Pallet et al. 2010; Talmon et al. 2010).

\section{Leflunomide}

\subsection{Drug generalities}

Leflunomide (Arava ${ }^{\circledR}$ ) is a disease-modifying antirheumatic drug (DMARD) used in adult patients with methotrexate intolerance, failure or loss of efficiency; it is also used in a second 
line to treat severe and active forms of psoriatic arthritis (Maddison et al. 2005; SanofiAventis 2009).

\subsection{Pharmacodynamy}

Its immunosuppressive action lies in the dihydroorotate dehydrogenase (DHOH) inhibition, an enzyme necessary for de novo synthesis of pyrimidic bases in lymphocytes. It also has an anti-proliferative action (Williamson et al. 1995; Fox et al. 1999).

Besides, leflunomide has proven abilities to reduce the viral proliferation for Human Cytomegalovirus (CMV), Herpes Simplex Viruses (HSV) in vitro (Knight et al. 2001) and respiratory syncytial virus (RSV) in vitro and in vivo (Dunn et al. 2011).

\subsection{Pharmacokinetics}

After per os administration, leflunomide is promptly and almost fully metabolized into its active form, terflunomide or A77 1726. This metabolism happens during first pass and consists in a carbon cycle opening in the intestinal wall and the liver. $95 \%$ of leflunomide is turned into A77 1726 this way, the remains into minor metabolites. Terflunomide is the drug responsible for the activity and side effects of leflunomide.

Leflunomide bioavailability is about $82 \%$ in healthy volunteers (Sanofi-Aventis 2009). Elimination plasma half-life of A77 1726 is quite considerable, with some 15 days in average. Patients are so compelled to take a $100 \mathrm{mg}$ charging dose for 3 days before a 10 to $20 \mathrm{mg}$ maintenance dose per day.

After a unique charging dose, A77 1726 Tmax is comprised between 6 and 12 hours, with a high inter-individual variability in patients with rheumatoid arthritis (Rozman 2002).

The volume of distribution $(\mathrm{Vd})$ is quite low, with about $12.7 \mathrm{~L}$ (6 to $30.8 \mathrm{~L}$ ), which is logical with its high affinity and linkage to albumin (99.4\% in healthy volunteers) (Rozman 2002). Elimination of A77 1726 is slow, it is characterized by an apparent clearance of $0.051 \mathrm{~L} / \mathrm{h}$ (Rozman 2002). This elimination is mostly renal (43\%) and biliary (48\%), as a consequence renal insufficiency alone does not significantly impair A77 1726 plasma concentrations (Beaman et al. 2002). Furthermore haemodialysis does not modify concentrations or clearance of A77 1726, which allows the patients to be on a dialysis without any dose adjustment. In vitro studies showed that cytochroms P450, in particular cytochroms 1A2, 2C19, 3A4 and 3A5 were involved in leflunomide metabolism (Kalgutkar et al. 2003). A pharmacogenetic study also showed the link between a polymorphism of cytochrom 1A2 and a risk of toxicity for patients with rheumatoid arthritis (Bohanec Grabar et al. 2008).

\subsection{Predictive efficiency}

In rheumatoid arthritis, plasma concentrations above $13 \mu \mathrm{g} / \mathrm{mL}$ seem to be efficient. These concentrations are usually reached with $20 \mathrm{mg}$ per day dosage (van Roon et al. 2005). Some authors tried to establish a relation between plasma concentrations and efficiency in patients with BK virus nephropathy, showing a tendency but with no absolute proof. Finally to date, no link between plasma concentrations and side effects has been shown (Bazin et al. 2009). Yet in vitro studies seem to show a predictive correlation between concentrations and the 
viral inhibitory effect: $10 \mu \mathrm{g} / \mathrm{mL}$ reduced the extracellular BKV load by $90 \%$ (IC90) but with significant host cytostatic effects (see figure 2) (Bernhoff et al. 2010).

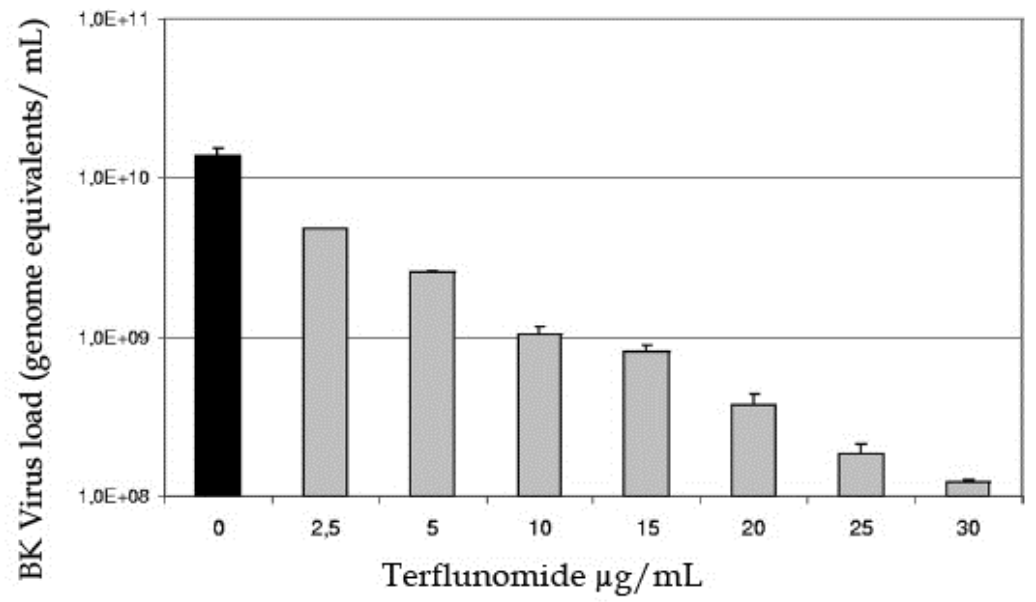

Fig. 2. Effect of Terflunomide on BK Virus load in vitro (Bernhoff et al. 2010)

\subsection{Mechanism of action}

Researches about the mechanism of leflunomide have recently been brightened. Leflunomide has two mechanisms of action: inhibition of dihydroorotate dehydrogenase, a key enzyme in the pyrimidine synthesis pathway, and tyrosine kinase inhibition. Dihydroorotate dehydrogenase inhibition is the primary mechanism involved in rheumatoid arthritis treatment. Interactions between the BK virus and the cellular protein kinase AKt / mammalian target of rapamycin (mTOR) pathway have been discovered (Liacini et al. 2010). These interactions are described in figure 3.

Akt (protein kinase B) is a serine/threonine kinase activated by growth factors, cytokines and mitogens (Fayard et al. 2010). The mTOR pathway which controls protein synthesis is located downstream of Akt. Akt indirectly activates mTOR. Two mTOR complexes have yet been described, mTOR complex 1 (mTORC1) which controls translation initiation, and mTOR complex 2 (mTORC2) which controls cytoskeletal changes and is also a $3^{\prime}$ phosphoinositide-dependent kinase-2 (PDK2), phosphorylating Akt, which may alter its substrate specificity (Bhaskar et al. 2007). Liacini et al showed that BK virus infecting renal tubular epithelial cells was able to activate the Akt/mTOR pathway; that leflunomide active metabolite, A77 1726 could inhibit PDK1 and Akt phosphorylation in a dose-dependent manner and in this way to reduce BK large $\mathrm{T}$ antigen expression and DNA replication. The combination of serine/threonine kinase inhibition of mTOR and tyrosine kinase inhibition significantly reduce the ability of the virus to survive and to produce new virions. More interesting though seems to be the combination of leflunomide and sirolimus targeting the Akt/mTOR pathway on different sites. Because both leflunomide and sirolimus possess immunosuppressive activity, this combination may allow treatment of BK virus-associated nephropathy without reduction of immunosuppression (Liacini et al. 2010). 


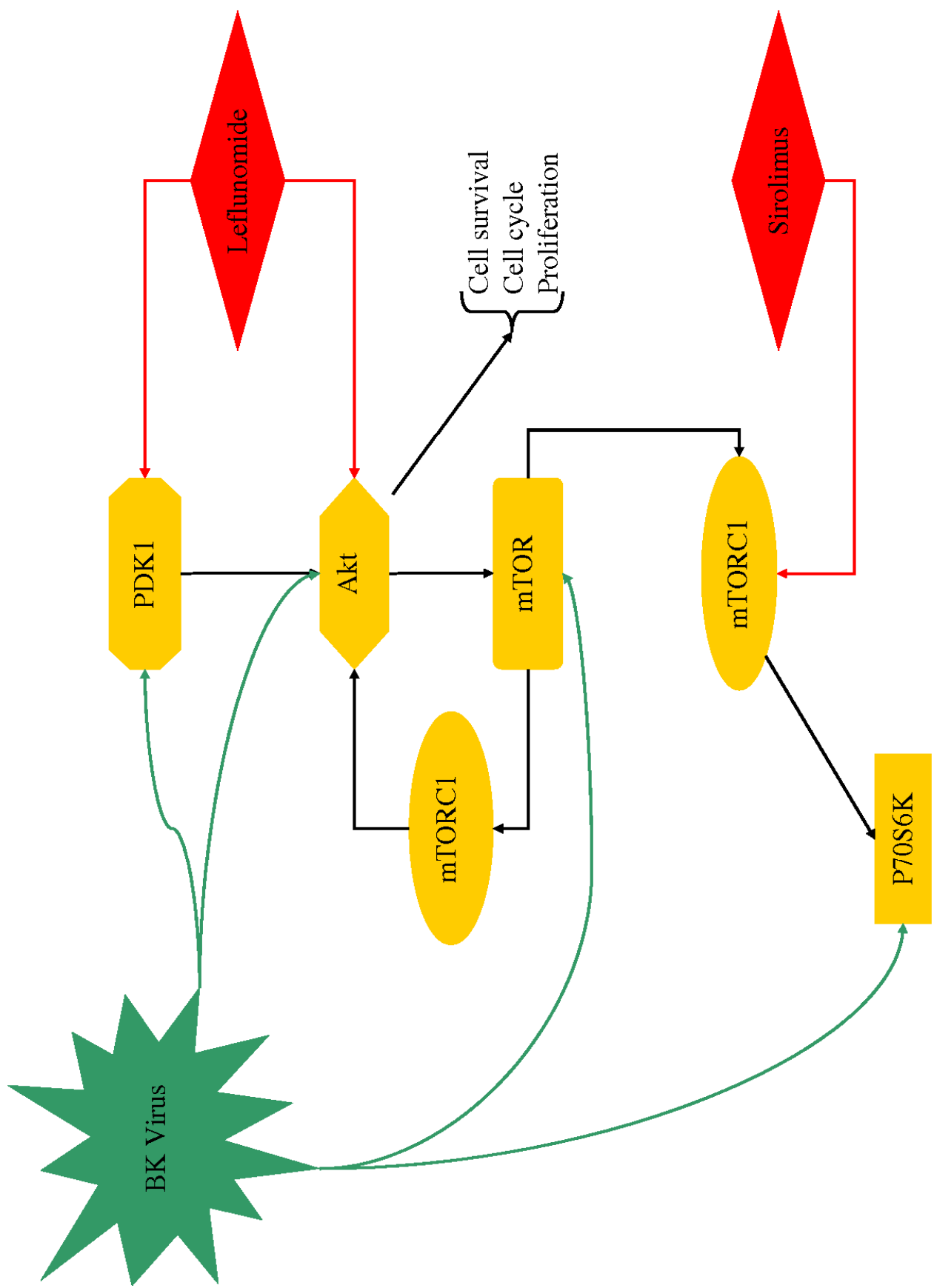

Fig. 3. Interactions between BK virus and inhibitors, sirolimus and leflunomide (Liacini et al. 2010) 
Results in terms of biological evolution in patients speak for itself. In a mean monitoring time of 16 months (12-24 months), viral load with leflunomide can be reduced about up to $50 \%$, and even be brought to undetectable, in blood like in urine. But more important is the lowering of renal failure and graft rejection thanks to this treatment. Creatinine clearance (Cockroft-Gault) can be stabilized and even improved (Bazin et al. 2009).

\subsection{Therapeutic drug monitoring}

Initial dosage for leflunomide is $20 \mathrm{mg}$ once a day, and can be raised to $30 \mathrm{or} 40 \mathrm{mg}$ for patients with viral loads remaining important. Plasma concentrations in therapeutic drug monitoring fluctuate between 15 and $135 \mu \mathrm{g} / \mathrm{mL}$. These concentrations set out low intraindividual but high inter-individual variability, and moreover without apparent correlation with prescribed dosage. It is interesting to notice that these concentrations were outside usual targets used in most studies - 50 to $100 \mu \mathrm{g} / \mathrm{mL}$ - which are supposed to offer the best efficiency and to limit the hepatotoxicity risk which can be lethal. Besides, the patient with the highest concentration - $135 \mu \mathrm{g} / \mathrm{mL}$ - had its viremia turned undetectable after only a two months treatment and showed no side effect of any kind. This result suggests that higher concentrations lead to higher efficacy and vice versa (Bazin et al. 2009).

\subsection{Tolerance}

Concerning tolerance, very few patients suffer from serious side effects. Loss of taste or lethargy can be observed but without any correlation with plasma concentrations. These side effects can prompt the treatment to be stopped, but in most cases viremia tends to increase strongly (Bazin et al. 2009).

\section{Discussion}

The main risk factor for BK virus-associated nephropathy is undeniably the immunosuppressive regimen intensity, in particular an intensification due to an acute rejection event (Binet et al. 1999; Nickeleit et al. 2000a; Barri et al. 2001; Nickeleit et al. 2003). Drugs in cause for these events seem to be the combination of tacrolimus, mycophenolate mofetil and monoclonal or polyclonal antibodies (Binet et al. 1999; Nickeleit et al. 1999; Nickeleit et al. 2000a; Nickeleit et al. 2003; Benavides et al. 2007). The organ and the graft type also play a role. For instance, Benavides et al. showed that the incidence of BK virusassociated nephropathy is higher in patients with kidney and pancreas rather than kidney alone; and that an alive donor would had a protective effect, probably explained by a lighter immunosuppressive regimen (Benavides et al. 2007).

Other risk factors have been evoked, like age and sex: nephropathy incidence seem to be greater for aged men (Ramos et al. 2002).

Furthermore many patients improve their symptoms at a distance of the surgery with the lowering of immunosuppression. We already have at our disposal a few experimental studies testing leflunomide on chronic or acute graft rejection (Williams et al. 1994; Xiao et al. 1995; Shen et al. 1998). More recently the inhibitory effects of leflunomide upon HSV, CMV and BK virus have been proved in vitro like in vivo (Waldman et al. 1999; Waldman et al. 1999; Knight et al. 2001; Farasati et al. 2005). Indeed a study suggests leflunomide is at 
least as efficient as ganciclovir in CMV infections and does not seem to be affected by resistant viruses (John et al. 2004). Leflunomide has even be successfully used in a patient with bone marrow graft and infected by a resistant virus to ganciclovir, foscarnet and cidofovir (Avery et al. 2004).

The studies where leflunomide is used as an immunosuppressive drug in renal and hepatic graft are more and more, because leflunomide allows to reduce anti-calcineurin drugs which have the major inconvenient of nephrotoxicity, and potentially protects aside from CMV, HSV and BK virus infections (Hardinger et al. 2002; Williams et al. 2002). Moreover leflunomide seems to be an interesting alternative in BK virus-associated nephropathy in renal transplant by eradicating detectable viremia in some patients. Leflunomide also allows avoiding rejection in most cases in spite of classical immunosuppressive drugs dosage reduction. Besides one of leflunomide's main asset is its absence of renal toxicity, contrary to cidofovir (Williams et al. 2005; Josephson et al. 2006; Teschner et al. 2006; Faguer et al. 2007).

Thanks to the encountered success in renal transplant, leflunomide is now used to treat hemorrhagic cystitis linked to BK virus in bone marrow transplant (Dropulic et al. 2008). However, due to the absence of randomized clinical trials with a sufficient number of patients, some authors consider its use in a first-line drug not recommended (Chon et al. 2011).

Leflunomide pharmacokinetics is characterized by a great inter-individual variability with terflunomide concentrations from 15 to $130 \mu \mathrm{g} / \mathrm{mL}$ obtained with the same dosage (Bazin et al. 2009). In BK virus infection, terflunomide concentrations between $15-30 \mu \mathrm{g} / \mathrm{mL}$ and 35 $100 \mu \mathrm{g} / \mathrm{mL}$ are sufficient to suppress respectively $50 \%$ and $90 \%$ of the replication for CMV and BK virus in vitro. That is why a therapeutic margin between 50 and $100 \mu \mathrm{g} / \mathrm{mL}$ has been proposed in this indication (Josephson et al. 2006). However, current strategic therapy so as to limit BK virus incidence tends to manage an early reduction of immunosuppressive regimen to avoid the apparition of a nephropathy. A prospective study with a significant number of patients would be probably necessary to definitely conclude about this relation between plasma concentrations and efficacy or in terms of rapidity of viral load eradication.

\section{Conclusion}

Leflunomide appears to be an alternative treatment in nephropathy due to BK virus in addition to lower immunosuppression regimen. In case of leflunomide use, a major standard seems to be high plasma terflunomide concentrations so as to obtain rapid virus eradication. Concentrations comprised between 15 and $60 \mu \mathrm{g} / \mathrm{mL}$ appear to be pertinent; these concentrations are usually reached with 20-40 mg per day. In patients with insufficient concentrations, further studies should be carried out to determine whether exists a benefit to use higher dosage up to 60 or $80 \mathrm{mg}$ a day. Even if tolerance is quite satisfying, it will probably be the most important parameter in such high-dose treatments.

Despite the small number of studies and the weak number of patients in each of them, a correlation seems to exist between plasma terflunomide concentrations and the treatment efficacy. This relation has not yet been proved with tolerance.

Due to its great inter-individual variability and alongside classical virological and clinical follow-up therapeutic drug monitoring appears to be an important step to take into care patients with BK virus related nephropathy. 


\section{Acknowledgment}

The author would like to acknowledge the staff of Henri-Mondor and Bicetre University Hospital Pharmacology laboratories and especially Anne Hulin, PharmD, PhD, Valerie Furlan, PharmD, PhD and Caroline Barau, PharmD.

\section{References}

Atencio, I. A., Shadan, F. F., Zhou, X. J., Vaziri, N. D. and Villarreal, L. P. (1993). "Adult mouse kidneys become permissive to acute polyomavirus infection and reactivate persistent infections in response to cellular damage and regeneration." J Virol 67(3): 1424-32.

Avery, R. K., Bolwell, B. J., Yen-Lieberman, B., Lurain, N., Waldman, W. J., Longworth, D. L., Taege, A. J., Mossad, S. B., Kohn, D., Long, J. R., Curtis, J., Kalaycio, M., Pohlman, B. and Williams, J. W. (2004). "Use of leflunomide in an allogeneic bone marrow transplant recipient with refractory cytomegalovirus infection." Bone Marrow Transplant 34(12): 1071-5.

Baksh, F. K., Finkelstein, S. D., Swalsky, P. A., Stoner, G. L., Ryschkewitsch, C. F. and Randhawa, P. (2001). "Molecular genotyping of BK and JC viruses in human polyomavirus-associated interstitial nephritis after renal transplantation." Am J Kidney Dis 38(2): 354-65.

Barri, Y. M., Ahmad, I., Ketel, B. L., Barone, G. W., Walker, P. D., Bonsib, S. M. and AbulEzz, S. R. (2001). "Polyoma viral infection in renal transplantation: the role of immunosuppressive therapy." Clin Transplant 15(4): 240-6.

Bazin, C., Barau, C., Grimbert, P., François, H., Blanchet, B., Astier, A., Furlan, V. and Hulin, A. (2009). "Etude pilote du suivi thérapeutique du Léflunomide en transplantation rénale." J Pharm Clin 28(1): 21-6.

Beaman, J. M., Hackett, L. P., Luxton, G. and Illett, K. F. (2002). "Effect of hemodialysis on leflunomide plasma concentrations." Ann Pharmacother 36(1): 75-7.

Benavides, C. A., Pollard, V. B., Mauiyyedi, S., Podder, H., Knight, R. and Kahan, B. D. (2007). "BK virus-associated nephropathy in sirolimus-treated renal transplant patients: incidence, course, and clinical outcomes." Transplantation 84(1): 83-8.

Bernhoff, E., Tylden, G. D., Kjerpeseth, L. J., Gutteberg, T. J., Hirsch, H. H. and Rinaldo, C. H. (2010). "Leflunomide inhibition of BK virus replication in renal tubular epithelial cells." J Virol 84(4): 2150-6.

Bhaskar, P. T. and Hay, N. (2007). "The two TORCs and Akt." Dev Cell 12(4): 487-502.

Binet, I., Nickeleit, V., Hirsch, H. H., Prince, O., Dalquen, P., Gudat, F., Mihatsch, M. J. and Thiel, G. (1999). "Polyomavirus disease under new immunosuppressive drugs: a cause of renal graft dysfunction and graft loss." Transplantation 67(6): 918-22.

Bohanec Grabar, P., Rozman, B., Tomsic, M., Suput, D., Logar, D. and Dolzan, V. (2008). "Genetic polymorphism of CYP1A2 and the toxicity of leflunomide treatment in rheumatoid arthritis patients." Eur J Clin Pharmacol 64(9): 871-6.

Boothpur, R. and Brennan, D. C. (2010). "Human polyoma viruses and disease with emphasis on clinical BK and JC." J Clin Virol 47(4): 306-12.

Brennan, D. C., Agha, I., Bohl, D. L., Schnitzler, M. A., Hardinger, K. L., Lockwood, M., Torrence, S., Schuessler, R., Roby, T., Gaudreault-Keener, M. and Storch, G. A. (2005). "Incidence of BK with tacrolimus versus cyclosporine and impact of preemptive immunosuppression reduction." Am J Transplant 5(3): 582-94. 
Brocker, V., Schwarz, A. and Becker, J. U. (2011). "[BK virus nephropathy after kidney transplantation.]." Pathologe.

Chen, C. H., Wen, M. C., Wang, M., Lian, J. D., Wu, M. J., Cheng, C. H., Shu, K. H. and Chang, D. (2001). "A regulatory region rearranged BK virus is associated with tubulointerstitial nephritis in a rejected renal allograft." J Med Virol 64(1): 82-8.

Chon, W. J. and Josephson, M. A. (2011). "Leflunomide in renal transplantation." Expert Rev Clin Immunol 7(3): 273-81.

De Luca, A., Giancola, M. L., Ammassari, A., Grisetti, S., Cingolani, A., Paglia, M. G., Govoni, A., Murri, R., Testa, L., Monforte, A. D. and Antinori, A. (2000). "Cidofovir added to HAART improves virological and clinical outcome in AIDS-associated progressive multifocal leukoencephalopathy." Aids 14(14): F117-21.

Dheir, H., Sahin, S., Uyar, M., Gurkan, A., Turunc, V., Kacar, S., Bayirli Turan, D. and Basdemir, G. (2011). "Intensive polyoma virus nephropathy treatment as a preferable approach for graft surveillance." Transplant Proc 43(3): 867-70.

Drachenberg, C. B., Beskow, C. O., Cangro, C. B., Bourquin, P. M., Simsir, A., Fink, J., Weir, M. R., Klassen, D. K., Bartlett, S. T. and Papadimitriou, J. C. (1999). "Human polyoma virus in renal allograft biopsies: morphological findings and correlation with urine cytology." Hum Pathol 30(8): 970-7.

Dropulic, L. K. and Jones, R. J. (2008). "Polyomavirus BK infection in blood and marrow transplant recipients." Bone Marrow Transplant 41(1): 11-8.

Dunn, M. C., Knight, D. A. and Waldman, W. J. (2011). "Inhibition of respiratory syncytial virus in vitro and in vivo by the immunosuppressive agent leflunomide." Antivir Ther 16(3): 309-17.

Faguer, S., Hirsch, H. H., Kamar, N., Guilbeau-Frugier, C., Ribes, D., Guitard, J., Esposito, L., Cointault, O., Modesto, A., Lavit, M., Mengelle, C. and Rostaing, L. (2007). "Leflunomide treatment for polyomavirus BK-associated nephropathy after kidney transplantation." Transpl Int 20(11): 962-9.

Farasati, N. A., Shapiro, R., Vats, A. and Randhawa, P. (2005). "Effect of leflunomide and cidofovir on replication of BK virus in an in vitro culture system." Transplantation 79(1): 116-8.

Fayard, E., Xue, G., Parcellier, A., Bozulic, L. and Hemmings, B. A. (2010). "Protein kinase B (PKB/Akt), a key mediator of the PI3K signaling pathway." Curr Top Microbiol Immunol 346: 31-56.

Fox, R. I., Herrmann, M. L., Frangou, C. G., Wahl, G. M., Morris, R. E., Strand, V. and Kirschbaum, B. J. (1999). "Mechanism of action for leflunomide in rheumatoid arthritis." Clin Immunol 93(3): 198-208.

Gilead (2010). "Vistide®." Résumé des Caractéristiques du Produit.

Gupta, A. and Gupta, P. (2011). "BK virus associated nephropathy in renal transplantation: where do we stand." Minerva Urol Nefrol 63(2): 155-67.

Hardinger, K. L., Koch, M. J., Bohl, D. J., Storch, G. A. and Brennan, D. C. (2010). "BK-virus and the impact of pre-emptive immunosuppression reduction: 5-year results." Am J Transplant 10(2): 407-15.

Hardinger, K. L., Wang, C. D., Schnitzler, M. A., Miller, B. W., Jendrisak, M. D., Shenoy, S., Lowell, J. A. and Brennan, D. C. (2002). "Prospective, pilot, open-label, short-term study of conversion to leflunomide reverses chronic renal allograft dysfunction." Am J Transplant 2(9): 867-71. 
Hirsch, H. H., Knowles, W., Dickenmann, M., Passweg, J., Klimkait, T., Mihatsch, M. J. and Steiger, J. (2002). "Prospective study of polyomavirus type BK replication and nephropathy in renal-transplant recipients." N Engl J Med 347(7): 488-96.

Hirsch, H. H., Mohaupt, M. and Klimkait, T. (2001). "Prospective monitoring of BK virus load after discontinuing sirolimus treatment in a renal transplant patient with BK virus nephropathy." J Infect Dis 184(11): 1494-5; author reply 1495-6.

John, G. T., Manivannan, J., Chandy, S., Peter, S. and Jacob, C. K. (2004). "Leflunomide therapy for cytomegalovirus disease in renal allograft recepients." Transplantation 77(9): 1460-1.

Johnston, O., Jaswal, D., Gill, J. S., Doucette, S., Fergusson, D. A. and Knoll, G. A. (2010). "Treatment of polyomavirus infection in kidney transplant recipients: a systematic review." Transplantation 89(9): 1057-70.

Josephson, M. A., Gillen, D., Javaid, B., Kadambi, P., Meehan, S., Foster, P., Harland, R., Thistlethwaite, R. J., Garfinkel, M., Atwood, W., Jordan, J., Sadhu, M., Millis, M. J. and Williams, J. (2006). "Treatment of renal allograft polyoma BK virus infection with leflunomide." Transplantation 81(5): 704-10.

Kadambi, P. V., Josephson, M. A., Williams, J., Corey, L., Jerome, K. R., Meehan, S. M. and Limaye, A. P. (2003). "Treatment of refractory BK virus-associated nephropathy with cidofovir." Am J Transplant 3(2): 186-91.

Kalgutkar, A. S., Nguyen, H. T., Vaz, A. D., Doan, A., Dalvie, D. K., McLeod, D. G. and Murray, J. C. (2003). "In vitro metabolism studies on the isoxazole ring scission in the anti-inflammatory agent lefluonomide to its active alpha-cyanoenol metabolite A771726: mechanistic similarities with the cytochrome P450-catalyzed dehydration of aldoximes." Drug Metab Dispos 31(10): 1240-50.

Knight, D. A., Hejmanowski, A. Q., Dierksheide, J. E., Williams, J. W., Chong, A. S. and Waldman, W. J. (2001). "Inhibition of herpes simplex virus type 1 by the experimental immunosuppressive agent leflunomide." Transplantation 71(1): 170-4.

Kuypers, D. R., Vandooren, A. K., Lerut, E., Evenepoel, P., Claes, K., Snoeck, R., Naesens, L. and Vanrenterghem, Y. (2005). "Adjuvant low-dose cidofovir therapy for BK polyomavirus interstitial nephritis in renal transplant recipients." Am J Transplant 5(8): 1997-2004.

Liacini, A., Seamone, M. E., Muruve, D. A. and Tibbles, L. A. (2010). "Anti-BK virus mechanisms of sirolimus and leflunomide alone and in combination: toward a new therapy for BK virus infection." Transplantation 90(12): 1450-7.

Maddison, P., Kiely, P., Kirkham, B., Lawson, T., Moots, R., Proudfoot, D., Reece, R., Scott, D., Sword, R., Taggart, A., Thwaites, C. and Williams, E. (2005). "Leflunomide in rheumatoid arthritis: recommendations through a process of consensus." Rheumatology (Oxford) 44(3): 280-6.

Mengel, M., Marwedel, M., Radermacher, J., Eden, G., Schwarz, A., Haller, H. and Kreipe, H. (2003). "Incidence of polyomavirus-nephropathy in renal allografts: influence of modern immunosuppressive drugs." Nephrol Dial Transplant 18(6): 1190-6.

Mylonakis, E., Goes, N., Rubin, R. H., Cosimi, A. B., Colvin, R. B. and Fishman, J. A. (2001). "BK virus in solid organ transplant recipients: an emerging syndrome." Transplantation 72(10): 1587-92.

Nickeleit, V., Hirsch, H. H., Binet, I. F., Gudat, F., Prince, O., Dalquen, P., Thiel, G. and Mihatsch, M. J. (1999). "Polyomavirus infection of renal allograft recipients: from latent infection to manifest disease." J Am Soc Nephrol 10(5): 1080-9. 
Nickeleit, V., Hirsch, H. H., Zeiler, M., Gudat, F., Prince, O., Thiel, G. and Mihatsch, M. J. (2000). "BK-virus nephropathy in renal transplants-tubular necrosis, MHC-class II expression and rejection in a puzzling game." Nephrol Dial Transplant 15(3): 324-32.

Nickeleit, V., Klimkait, T., Binet, I. F., Dalquen, P., Del Zenero, V., Thiel, G., Mihatsch, M. J. and Hirsch, H. H. (2000). "Testing for polyomavirus type BK DNA in plasma to identify renal-allograft recipients with viral nephropathy." N Engl J Med 342(18): 1309-15.

Nickeleit, V., Singh, H. K. and Mihatsch, M. J. (2003). "Polyomavirus nephropathy: morphology, pathophysiology, and clinical management." Curr Opin Nephrol Hypertens 12(6): 599-605.

Nickeleit, V., Zeiler, M., Gudat, F., Thiel, G. and Mihatsch, M. J. (1998). "Histological characteristics of interstitial renal allograft rejection." Kidney Blood Press Res 21(2-4): 230-2.

Pallet, N., Burgard, M., Quamouss, O., Rabant, M., Bererhi, L., Martinez, F., Thervet, E., Anglicheau, D., Noel, L. H., Rouzioux, C. and Legendre, C. (2010). "Cidofovir may be deleterious in BK virus-associated nephropathy." Transplantation 89(12): 1542-4.

Pavlakis, M., Haririan, A. and Klassen, D. K. (2006). "BK virus infection after non-renal transplantation." Adv Exp Med Biol 577: 185-9.

Ramos, E., Drachenberg, C. B., Papadimitriou, J. C., Hamze, O., Fink, J. C., Klassen, D. K., Drachenberg, R. C., Wiland, A., Wali, R., Cangro, C. B., Schweitzer, E., Bartlett, S. T. and Weir, M. R. (2002). "Clinical course of polyoma virus nephropathy in 67 renal transplant patients." J Am Soc Nephrol 13(8): 2145-51.

Randhawa, P., Ho, A., Shapiro, R., Vats, A., Swalsky, P., Finkelstein, S., Uhrmacher, J. and Weck, K. (2004). "Correlates of quantitative measurement of BK polyomavirus (BKV) DNA with clinical course of BKV infection in renal transplant patients." J Clin Microbiol 42(3): 1176-80.

Randhawa, P. S. and Demetris, A. J. (2000). "Nephropathy due to polyomavirus type BK." N Engl J Med 342(18): 1361-3.

Randhawa, P. S., Khaleel-Ur-Rehman, K., Swalsky, P. A., Vats, A., Scantlebury, V., Shapiro, R. and Finkelstein, S. (2002). "DNA sequencing of viral capsid protein VP-1 region in patients with BK virus interstitial nephritis." Transplantation 73(7): 1090-4.

Rosenberg, A. S. and Singer, A. (1992). "Cellular basis of skin allograft rejection: an in vivo model of immune-mediated tissue destruction." Annu Rev Immunol 10: 333-58.

Rozman, B. (2002). "Clinical pharmacokinetics of leflunomide." Clin Pharmacokinet 41(6): 421-30.

Saad, E. R., Bresnahan, B. A., Cohen, E. P., Lu, N., Orentas, R. J., Vasudev, B. and Hariharan, S. (2008). "Successful treatment of BK viremia using reduction in immunosuppression without antiviral therapy." Transplantation 85(6): 850-4.

Sanofi-Aventis (2009). "Arava ${ }^{\circledR}$." Résumé des Caractéristiques du Produit.

Seron, D., Alexopoulos, E., Raftery, M. J., Hartley, R. B. and Cameron, J. S. (1989). "Diagnosis of rejection in renal allograft biopsies using the presence of activated and proliferating cells." Transplantation 47(5): 811-6.

Shen, J., Chong, A. S., Xiao, F., Liu, W., Huang, W., Blinder, L., Foster, P., Sankary, H., Jensik, S., McChesney, L., Mital, D. and Williams, J. W. (1998). "Histological characterization and pharmacological control of chronic rejection in xenogeneic and allogeneic heart transplantation." Transplantation 66(6): 692-8.

Smith, R. D., Galla, J. H., Skahan, K., Anderson, P., Linnemann, C. C., Jr., Ault, G. S., Ryschkewitsch, C. F. and Stoner, G. L. (1998). "Tubulointerstitial nephritis due to a 
mutant polyomavirus BK virus strain, BKV(Cin), causing end-stage renal disease." J Clin Microbiol 36(6): 1660-5.

Talmon, G., Cornell, L. D. and Lager, D. J. (2010). "Mitochondrial changes in cidofovir therapy for BK virus nephropathy." Transplant Proc 42(5): 1713-5.

Teschner, S., Geyer, M., Wilpert, J., Schwertfeger, E., Schenk, T., Walz, G. and Donauer, J. (2006). "Remission of polyomavirus-induced graft nephropathy treated with lowdose leflunomide." Nephrol Dial Transplant 21(7): 2039-40.

van Roon, E. N., Jansen, T. L., van de Laar, M. A., Janssen, M., Yska, J. P., Keuper, R., Houtman, P. M. and Brouwers, J. R. (2005). "Therapeutic drug monitoring of A77 1726, the active metabolite of leflunomide: serum concentrations predict response to treatment in patients with rheumatoid arthritis." Ann Rheum Dis 64(4): 569-74.

von Willebrand, E., Pettersson, E., Ahonen, J. and Hayry, P. (1986). "CMV infection, class II antigen expression, and human kidney allograft rejection." Transplantation 42(4): 364-7.

Waldman, W. J., Knight, D. A., Blinder, L., Shen, J., Lurain, N. S., Miller, D. M., Sedmak, D. D., Williams, J. W. and Chong, A. S. (1999). "Inhibition of cytomegalovirus in vitro and in vivo by the experimental immunosuppressive agent leflunomide." Intervirology 42(5-6): 412-8.

Waldman, W. J., Knight, D. A., Lurain, N. S., Miller, D. M., Sedmak, D. D., Williams, J. W. and Chong, A. S. (1999). "Novel mechanism of inhibition of cytomegalovirus by the experimental immunosuppressive agent leflunomide." Transplantation 68(6): 814-25.

Weiss, A. S., Gralla, J., Chan, L., Klem, P. and Wiseman, A. C. (2008). "Aggressive immunosuppression minimization reduces graft loss following diagnosis of BK virus-associated nephropathy: a comparison of two reduction strategies." Clin J Am Soc Nephrol 3(6): 1812-9.

Williams, J. W., Javaid, B., Kadambi, P. V., Gillen, D., Harland, R., Thistlewaite, J. R., Garfinkel, M., Foster, P., Atwood, W., Millis, J. M., Meehan, S. M. and Josephson, M. A. (2005). "Leflunomide for polyomavirus type BK nephropathy." N Engl J Med 352(11): 1157-8.

Williams, J. W., Mital, D., Chong, A., Kottayil, A., Millis, M., Longstreth, J., Huang, W., Brady, L. and Jensik, S. (2002). "Experiences with leflunomide in solid organ transplantation." Transplantation 73(3): 358-66.

Williams, J. W., Xiao, F., Foster, P., Clardy, C., McChesney, L., Sankary, H. and Chong, A. S. (1994). "Leflunomide in experimental transplantation. Control of rejection and alloantibody production, reversal of acute rejection, and interaction with cyclosporine." Transplantation 57(8): 1223-31.

Williamson, R. A., Yea, C. M., Robson, P. A., Curnock, A. P., Gadher, S., Hambleton, A. B., Woodward, K., Bruneau, J. M., Hambleton, P., Moss, D., Thomson, T. A., SpinellaJaegle, S., Morand, P., Courtin, O., Sautes, C., Westwood, R., Hercend, T., Kuo, E. A. and Ruuth, E. (1995). "Dihydroorotate dehydrogenase is a high affinity binding protein for A77 1726 and mediator of a range of biological effects of the immunomodulatory compound." J Biol Chem 270(38): 22467-72.

Xiao, F., Chong, A., Shen, J., Yang, J., Short, J., Foster, P., Sankary, H., Jensik, S., Mital, D., McChesney, L. and et al. (1995). "Pharmacologically induced regression of chronic transplant rejection." Transplantation 60(10): 1065-72. 


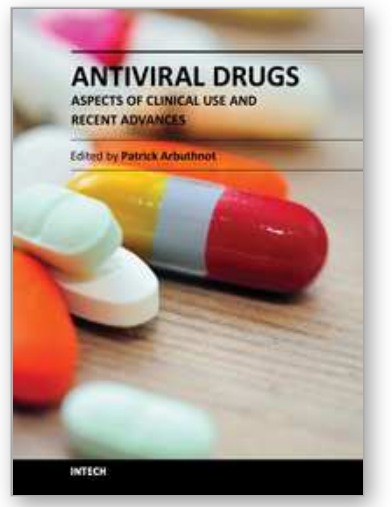

\author{
Antiviral Drugs - Aspects of Clinical Use and Recent Advances \\ Edited by Dr. Patrick Arbuthnot
}

ISBN 978-953-51-0256-4

Hard cover, 194 pages

Publisher InTech

Published online 14, March, 2012

Published in print edition March, 2012

The articles that appear in Antiviral Drugs - Aspects of Clinical Use and Recent Advances cover several topics that reflect the varied mechanisms of viral disease pathogenesis and treatment. Clinical management and new developments in the treatment of virus-related diseases are the two main sections of the book. The first part reviews the treatment of hepatitis $C$ virus infection, the management of virus-related acute retinal necrosis, the use of leflunomide therapy in renal transplant patients, and mathematical modeling of HIV-1 treatment responses. Basic research topics are dealt with in the second half of the book. New developments in the treatment of the influenza virus, the use of animal models for HIV-1 drug development, the use of single chain camelid antibodies against negative strand RNA viruses, countering norovirus infection, and the use of plant extracts to treat herpes simplex virus infection are described. The content of the book is not intended to be comprehensive, but aims to provide the reader with insights into selected aspects of established and new viral therapies.

\title{
How to reference
}

In order to correctly reference this scholarly work, feel free to copy and paste the following:

Christophe Bazin (2012). Leflunomide an Immunosuppressive Drug for Antiviral Purpose in Treatment for BK Virus-Associated Nephropathy After Kidney Transplantation, Antiviral Drugs - Aspects of Clinical Use and Recent Advances, Dr. Patrick Arbuthnot (Ed.), ISBN: 978-953-51-0256-4, InTech, Available from:

http://www.intechopen.com/books/antiviral-drugs-aspects-of-clinical-use-and-recent-advances/leflunomide-animmunosuppressive-drug-for-antiviral-purpose-in-treatment-for-bk-virus-nephropathy-af

\section{INTECH}

open science | open minds

\section{InTech Europe}

University Campus STeP Ri

Slavka Krautzeka 83/A

51000 Rijeka, Croatia

Phone: +385 (51) 770447

Fax: +385 (51) 686166

www.intechopen.com

\section{InTech China}

Unit 405, Office Block, Hotel Equatorial Shanghai

No.65, Yan An Road (West), Shanghai, 200040, China 中国上海市延安西路65号上海国际贵都大饭店办公楼405单元

Phone: +86-21-62489820

Fax: $+86-21-62489821$ 
(C) 2012 The Author(s). Licensee IntechOpen. This is an open access article distributed under the terms of the Creative Commons Attribution 3.0 License, which permits unrestricted use, distribution, and reproduction in any medium, provided the original work is properly cited. 